\title{
INDIWIDUELE VRYHEID EN GEBONDENHEID IN DIE PATROON VAN RASSEVERHOUDINGS
}

\begin{abstract}
Akademiese vryheid nieteenstaande, is dit ook vir die wetenskaplike nodig om sy gehoor in te lig aangaande die grondslag in sy benadering van 'n onderwerp. Dit is te meer noodsaaklik waar die onderwerp van so 'n besondere en besproke aard is soos die onderhawige en waar ,vryheid', indiwidueel en akademies, reeds tot emosionele slagspreukwaarde in die patroon van rasseverhoudings verhef is, of miskien beter neergetrek is. Ek wil derhalwe reg aan die begin ' $n$ belydenis doen - noem dit maar die belydenis van 'n volkekundige wat die mens in al die fasette van sy bestaan, fisies, sosiaal-kultureel en religieus, trag te bestudeer, te begryp en te waardeer. Ek aanvaar dat hierdie belydenis voor akademici en studente aan 'n Christelik-gefundeerde Universiteit nie misplaas sal wees nie. Maar ook die plek van belydenis sal aan die wetenskaplike oortuiging waarmee ek bely nie verskil maak nie.

As wetenskaplike soeker na die waarheid bely ek dat ek in my soektog twee waardesisteme in berekening bring wat, na my mening, albei die mens in sy denke en handelwyse beïnvloed. Hierdie twee waardesistema kan ek omlyn as:

(a) Die naturalistiese waardesisteem wat fisies-materialisties gebonde is en sy kennisvlak verbreed binne die aardse konsep en bestaan; en

(b) Die supernaturalistiese waardesisteem wat nie fisiesmaterialisties gebonde is nie, en sy kennisvlak verbreed binne die religieuse konsep en geloof.

Dit is my objektiewe beskouing dat enige wetenskaplike wat die een of ander van hierdie twee waardesisteme buite rekening laat, ' $n$ denkfout begaan. Om die probleem van ,vryheid' en ,gebondenheid' in die patroon van rasseverhoudings in regte perspektief te stel, is dit na my mening die wetenskaplike se plig om albei waardesisteme in berekening te bring.

Laat my die saak helder en in praktiese taal stel. In die patroon van rasseverhoudings in Suid-Afrika is daar vandag ' $n$ veelvoudigheid van persone, liggame en instansies wat benadering wil bepaal. Vanselfsprekend is dit belangrik dat hierdie dringende vraagstuk soveel aandag geniet. Dit is egter ook
\end{abstract}


waar dat ' $n$ analise van die belangstellende instansies ' $n$ tweeledige groepering na vore bring. Eerstens is daar dié groep wat hulle benadering baseer op die mens as vrye wese binne aardse verband. Die klem val hier dan gewoonlik op vryheid, gelykheid en broederskap in mindere of meerdere mate binne gemeenskapsverband. Binne hierdie groep is daar twee uiteenlopende denkrigtings, naamlik voorstanders van:

(a) 'n Homogene gemeenskap sonder differensiëring op enige vlak m.a.w. 'n geïntegreerde eenheid waar verskille en anderssoortigheid geen betekenis het nie.

(b) 'n Heterogene gemeenskap waar verskille en andersoortigheid erken word in die ordereëlings.

In die omgangstaal staan hierdie twee denkrigtings bekend as voorsprake vir integrasie enersyds en afsonderlike ontwikkeling andersyds. Dit gaan hier dus om norme by die bepaling van 'n samehorige gemeenskap m.a.w. of die uitgangspunt slegs menswese as sodanig is, en of andersoortige menswese in berekening gebring word. Let wel, geen denkende sal as norm neem minderwaardige of meerderwaardige menswese nie. Indien daar diesulkes is, is hulle nie van betekenis vir akademiese bespreking nie.

Die tweede groep baseer hulle benadering op die siening van die mens as onsterflike wese vir wie aardse bestaan slegs 'n tussenfase is en wie se uiteindelike bestemming ' $n$ beslissing vir die Bonatuurlike is. Ook onder hierdie groep vind ons twee uiteenlopende denkrigtings naamlik:

(a) Diegene wat die algemene gelykwaardigheid van die mens voor sy Skepper sien as 'n implisering van aardse gelykheid sonder differensiasie.

(b) Diegene wat die algemene gelykwaardigheid van die mens voor sy Skepper erken, maar differensiasie onderskryf as deel van die skeppingsplan binne aardse verband. $\mathrm{U}$ sal weet dat die twee groepe wat benadering van rasseverhoudings trag te bepaal soos hierbo omlyn op die akademiese vlak veral sosiaal-wetenskaplikes en teoloë insluit. Hierby kom natuurlik nog politici, studente, gewone mense en so meer wat hulle ook met die vraagstuk besig hou. Van belang is egter die feit dat watter groep ook al uitgesonder word, verskille in denkrigtings bestaan binne elke groep. In hierdie maalstroom van denkverskeidenheid moet die ernstige denker van ons tyd vir homself ' $n$ belangrike vraag afvra naamlik: 
Wat is my indiwiduele vryheid en wat is my gebondenheid ten opsigte van rasseverhoudings?

Laat my al dadelik sê dat die begrip indiwiduele vryheid nie vertolk moet word as losbandigheid nie, en dat gebondenheid nie noodwendig slawerny is nie. Albei hierdie begrippe is slegs vertolkbaar wanneer die mens gesien word, nie as enkeling nie, maar as deel van 'n gemeenskap. Indiwiduele vryheid buite ' $n$ gemeenskap is ' $n$ kluisenaarsbestaan. Sonder ' $n$ gemeenskap kan daar nie gebondenheid wees nie, want dit is die gemeenskap wat grense bepaal. Die logiese afleiding is dus dat indiwiduele vryheid en gebondenheid slegs in gemeenskapsverband betekenis kry. Dit is van die grootste belang by ons bespreking, want dit is die gemeenskap wat waardesisteme bepaal en koester.

\section{DIE FISIESE VLAK}

Vir die wetenskaplike dra die term ras slegs 'n biologiese begrip. Skynbaar afkomstig van die Arabiese woord ra's (oorsprong) is dit 'n geleende term in die Westerse tale. Maar selde in die geskiedenis van die mensdom het 'n enkele begrip soveel verwarring en kwade emosies opgewek as die begrip ras in die huidige wêreld. As biologiese verskynsel is rasseverskeidenheid by die mens 'n waarneembare feit. Die fisiese andersoortigheid van verskillende mensgroepe het egter ook vir baie dekades reeds as norm gedien in die inherente waardebepaling van menssoorte. Dit het veral normatiewe vorm aangeneem in die publikasies van die Franse skrywer De Gobineau en het sedertdien aan talle polemiese geskrifte geboorte gegee. Nieteenstaande die uitgesproke geskrifte van o.a. Unesco oor die kwaliteitswaarde van rasverskille, is dit 'n aangeleentheid waaroor daar nog geen volkome wetenskaplike helderheid bestaan nie, en waarop daar dus nie na een of ander rigting met suiwer wetenskaplike fundering gebou kan word nie. Vanselfsprekend kan kwaliteitswaarde van rasseverskille dus ook nie ingeroep word as maatstaf om fisiese verhoudings tussen rasverskillende mense te bepaal nie. Maar juis hierdie onsekerheid maak eksperimente in rassevermenging gevaarlik, omdat die totaalsom van die eindresultaat nie bepaalbaar is nie, en die eindresultaat ook nie weer herleibaar is tot sy komponerende elemente nie.

Omrede die onsekere aard van die kwaliteitswaarde van 
rasseverskille moet die norm van verhouding op die fisiese vlak elders gesoek word, en dit kan slegs gesoek word in dic onomstootbare feit van verskeidenheid en andersoortigheid. 'n Ras soos ons dit by die mens verstaan is ,' $n$ partikuliere tipe of mensegroep waarvan elke indiwidu wat daaronder tuishoort, die gemiddelde somatiese (fisiese) trekke openbaar wat kenmerkend is van sy bepalde tipe soos eerstens oorgeerf is van sy tipiese ouers en tweedens oordraagbaar is op sy tipiese kroos". ${ }^{\text {) }}$

Die logiese vraag wat nou na vore kom is dié van indiwiduele vryheid en gebondenheid in die fïsiese verhouding tussen mense van verskillende rasgroepe. Is dit m.a.w. geoorloof vir die indiwidu om vry en ongebonde die fisiese aard van sy kroos te bepaal en daardeur moontlik die fisiese aard van sy groep te verander? Die antwoord op hierdie vraag lê in die morele verpligting van elke mens om hom te weerhou van vernietiging wat ook sy medemens skaad. Nou is dit so dat geen indiwidu sy eie biologiese uiterlik as verteenwoordiger van 'n bepaalde rastipe kan verander nie. Die biologiese uiterlik van sy kroos kan hy wel beïnvloed deur die keuse van sy egmaat. Indien indiwiduele vryheid hier volkome moel seëvier soos deur sommige wat gemengde verhoudings op die fisiese vlak voorstaan as die vrye reg van die indiwidu, dan word 'n indiwiduele vryheid beoefen wat 'n nagevolg het op ander indiwidue wat oor die aangeleentheid geen seggenskap het nie. Die een geslag word dan in 'n rasgebondenheid geplaas deur die indiwiduele vryheid wat die ander geslag homself veroorloof. Geen wonder dat Oswald Spengler skryf: „The blood is for us the symbol of living. Its course proceeds without pause, from generation to death, from the mother body in waking state and in sleep, never ending. The blood of the ancestors flows through the chain of the generations and binds them in a great linkage of destiny and... time". ${ }^{2}$ )

Wanneer indiwiduele vryheid in verhoudings op die fisiese vlak beklemtoon word, moet daar terselfdertyd ook verantwoording gedoen word van die resultaat van sodanige indiwiduele vryheid. Carr-Saunders skryf oor die posisie van mengtipes as volg: „The mulatto is neither of one race nor of the other, and he knows it. He is an outcast. There is no tradition which he naturally absorbs. He neither grows up with the pride of the white man nor with the feeling of community with his coloured relatives... In the world of tradition there 
is no home for him'.3) Dit is 'n harde oordeel wat selfs miskien nie altyd en oral waar is nie. Maar dit stem tot naclenke wanneer die indiwidu homself vryhede veroorloof op die fisiese verhoudingsvlak sonder dat hy die gevolge volkome kan kontroleer.

Veroorloof my 'n laaste aanhaling voordat ek hierdie deel afsluit. Roger Pearson skryf: "Today mankind, in the conceit of new knowledge and new technological power, seeks to destroy the biological and evolutionary structure on which the whole edifice of human progress is raised, and seeks to discard the work of thousands of generations of ... shaping. We can only prevent the destruction of this edifice if we take it upon ourselves to overcome our inherent shyness of such topics, to forget that we might possibly say something that might offend our neighbours, and start talking about race, racial hygiene and human eugenics. Only thus can we ensure that our children and their children will be able to find the partners that we would select for ourselves in marriage..."1)

Wanneer al die fisiese en morele implikasies van mengverhoudings op die fisiese vlak in oënskou geneem word, kan die eerlike denker moeilik tot 'n ander gevolgtrekking kom as dat dic slagspreuk van indiwiduele vryheid in hierdie verband, 'n mistasting is van vryheid met verantwoordelikheid. Indiuiduele vryheid sonder die beskermende gebondenheid binne die waardesisteem van die gemeenskap kan dus op die vlak van fisiese mengverhoudings slegs 'n gevaarlike eksperiment wees wat die indiwidu uitvoer ten koste van die groep want, sê Roger Pearson: "Modern genetics shows us... that once eugenic patterns get confused, as they do in cross marriages between different species and different races, and between the fit and the unfit, it is rarely possible to eradicate defects..." 5 ).

Die sociaal-wetenskaplike wat sy slagspreuk van volkome indiwiduele vryheid fundeer op sy siening van 'n homogene gemeenskap sonder differensiasie, moet, as hy eerlik dink, kennis neem van die fisiese implikasies van mengverhoudings op die biologiese vlak. Die teoloog wat in religieuse sin die gelykwaardigheid van die mens voor sy Skepper projekteer as 'n aardse gelykheid sonder differensiasie, moet hom vergewis van die morele implikasies van mengverhoudings op die biologiese vlak. Niemand kan die indiwidu uitlig uit sy groep en aan hom 'n vryheid toeken wat die groep noodwendig moet 
skaad nie. Daarom bly gebondenheid binne die waardesisteem van die groep vir die huidige met die kennis waaroor ons vandag beskik die enigste suiwere en veilige norm om die verhouding tussen rasverskillende mense op die biologiese vlak te bepaal. Oldham som die posisie as volg op: „... the individual who refuses to see things as they still appear to the mass of his countrymen, and who simply argues academically on all so-called colour questions... is not worthy of being read..."6)

\section{DIE SOSIO-KULTURELE VLAK}

Indien die waardesisteme van die gemeenskap dan die indiwiduele vryheid noodwendig moet begrens op die vlak van fisies-biologiese verhoudings tussen rasverskillende mense, ontstaan die vraag wat dan die omvang van indiwiduele vryheid en wat die grense van gebondenheid is op die sosio-kulturele vlak. Filosofies gesien behels die vraag die volgende probleem: Gestel die moontlikheid dat biologiese vermenging uitgeskakel kan word, is indiwiduele vryheid sonder enige vorm van gebondenheid dan in rasseverhoudings geoorloof as 'n suiwer gefundeerde norm? In praktiese sin beteken die vraag of sosiale, ekonomiese en politieke integrasie sonder biologiese integrasie aanvaarbaar is as 'n gesonde ordereëling in 'n rasheterogene gemeenskap.

Genoemde filosofiese vraag is 'n probleem waarmee die objektiewe denker seker die swaarste sou moes worstel indien dit 'n praktiese inslag gehad het. Dit gaan hier nie om fisiese norme nie, maar wel om die gelykmatige deling van sosiokulturele waardes binne 'n eenheidsgemeenskap waarin die lede slegs fisies gedifferensieerd sou bly. Die filosofiese vraag het egter nie praktiese betekenis nie aangesien sosiale, ekonomiese en politieke integrasie van rasverskillende bevolkingselemente nie biologiese integrasie kan uitskakel nie, want die rasverskillende elemente van die eenheidsgemeenskap is in feite onderling vrugbaar. Verhoudings op die sosio-kulturele vlak is in die eerste instansie menseverhoudings, maar dit kan nie geskei word van rasseverhoudings in biologiese sin nie, want in albei gevalle moet die noodwendige gevolg van volkome indiwiduele vryheid sonder die gebondenheid binne die waardesisteme van die groep, die groep in sy wese aantas. Sonder die instemming van die groep as sodanig is so 'n 
aantasting nie geregverdig nie. Dit inderdaad is die grondslag waarop die demokratiese lewensbeskouing berus.

Die vraag is dan wat bepaal die gebondenheid van die indiwidu aan die waardesisteme van sy groep op die sosiokulturele vlak? Kultuur is die somtotaal van die mens se eie skeppingsvernuf en sluit in sy sosiale, materiële en geestelike waardesisteme. Kultuur is nie rasgebonde nie, omdat dit wel deur diffusie en andersins oordraagbaar en assimileerbaar is. Maar in feite bestaan daar partikuliere kultuurpatrone eiesoortig aan 'n bepaalde kultuurvolk en andersoortig in wese van ander partikuliere kultuurpatrone. Die andersoortigheid in kultuurpatrone word bepaal deur die besondere waardesisteme inherent in die kultuur soos gesanksioneer deur die draers daarvan. Walter sê in hierdie verband: „The culture group is the population which is the carrier of a particular and distinctive culture. Since culture is a human product and always essentially physic in nature it follows that no culture can exist except when its meanings are rooted in the minds of people who transmit them to the minds of their offspring thus perpetuating them through time..."7)

Dit volg uit die essensie van hierdie aanhaling dat elke indiuidu 'n skakel is in die kultuurtradisie van sy kultuurvolk, en dit sou slegs 'n onverantwoordelike wees wat kan beweer dat die indiwidu die vryheid het om daardie ketting te verbreek sonder die sanksie van sy groep.

Dit is waar dat daar in die vloed van geskrifte oor verhoudings in die wêrelddenke van vandag, 'n noot van kulturele gelykmaking gehoor word. As rede word aangegee dat die tegnologiese ontwikkeling van die mens 'n gelykmakende effek het. Die denkfout in hierdie redenasie lê egter daarin dat die materiële beklemtoon word met 'n totale negasie van die diepere geestelike waardesisteme wat per slot van sake die veredelende dryfkrag in enige kultuur is. Maar die feite staaf ook nie die argument nie. Japan het nieteenstaande sy uitsonderlike tegnologiese ontwikkeling nog 'n eie kultuuridentiteit. En wie sou kon beweer dat dit foutief is van die Japannese om in die pragontwikkeling van hulle tegnologie 'n eie kultuuridentiteit te handhaaf? Lê ware vryheid nie juis daarin dat die kultuurvolk wat per slot van sake die totaalsom van komponerende indiwidue is, ook op sosio-kulturele vlak 'n selfbeskikkingsreg het nie? As sy vreugde en menslike waardigheid weerspieël word in die aanvaarding van die waarde- 
sisteem van sy groep, dan is sy indiwiduele vryheid eg en sy gebondenheid binne ' $n$ groep 'n waarborg van daardie vryheid. Waardesisteme is nie almal enerssoortig nie, maar soos ' $n$ Christen-leier dit cenkeer uitgedruk het: „There need be no lurking assumption of superiority, no haunting sense of inferiority in recognising frankly the fact of difference..." ${ }^{8}$ )

Wanneer 'n beroep gedoen word op indiwiduele vryheid op die vlak van sosio-kulturele menseverhoudings, is dit ook nodig dat diegene wat die beroep doen hulle vergewis van die resultate van losskeuring van 'n eie kulturele waardesisteem. Ons kan hierop nie breedvoerig ingaan nie, maar slegs die feit konstateer dat sodanige losskeuring gewoonlik 'n kulturele lugleegte laat wat mank gaan aan 'n innerlik aangevoelde waardesisteem. Dit is van sodaniges dat die Bantoeskrywer Vilikazi sê: „They have thrown away traditional ways but have not put anything in their stead... They are the amagxagxa who, like Bunyan's Christian, are wallowing in a confused cultural slough of despond. They have no set standards of behaviour, have not achieved any integration and their morality is convenience and/or expedience..." 9 )

Die Katolieke pater Tempels vra in sy werk Bantoe-Filosofie die vraag hoeveel, geciviliseerden of waarlik geëvolueerden' ons reeds onder die Bantoe van Afrika kan tel. En dan antwoord hy self as volg: „Ontwortelden en gedegenereerden zoveel men wil. Materialisten, die geen houvast meer hebben aan die filosofische nalatenschap hunner vaderen, noch aan de christelijke wereldbeschouwing en de filosofie der blankes, zijn er bij de vleet. Of wel bleven zij volledig "muntu" onder het vernis der na-aperij ..." ${ }^{10}$ )

Die indiwidu wat hom stel op indiwiduele vryheid sonder die gebondenheid van die waardesisteme van 'n groep, moet verantwoording doen van die resultate wat hy skep soos geskets deur Vilikazi en Tempels in bostaande aanhalings. Maar Tempels se siening is ook ' $n$ antwoord aan diegene wat beweer dat die sogenaamde geëvolueerdes van 'n ander groep in 'n cenheidsgemeenskap opgeneem moet word op grond van ,peil van beskawing'. Hoe ver strek die innerlike aanvoeling en aanvaarding van die waardesisteme van 'n vreemde kultuurmilieu? Enigiemand wat objektief die posisie in kontemporêre Afrika ontleed, moet tot die slotsom kom dat die waardesisteme van die Westerse bedeling wat Afrika vir die laaste 
eeu beklee het, min innerlike indruk gemaak het. Die skrywer Jahn sê in hierdie verband die volgende:

„The Africans naturally fall back on their own system of belief, value and feeling. The more independent, farsighted and sensitive the African, the stronger will be his reaction. Elements of the old culture such as for example the ritualistic attitude to livestock, to African music, to dances and amusement, are revived with a new, almost ethnographic interest in racial history, traditional law, and the artistic and intellectual achievement of their own race..." 11 )

Bostaande aanhalings beklemtoon die voortdurende krag van die waardesisteme van 'n groep en weerspieël die onuitwisbare aanvoeling vir daardie waardesisteme. Wanneer die beoefening van indiuiduele vryheid hierdie waardesisteme aantas, dan pleeg die indiwidu verraad teenoor die skeppinge van sy groep. Hy pleeg verraad omdat hy die fondamente vernietig waarop 'n edeler toekoms gebou kan word. Tereg sê Tempels: „Het is maar van de juiste, oeroude, goede inlandsche basis uit, dat we de Bantu kunnen brengen tot de enige ware Bantubeschawing..."12) En wat in hierdie sin van die Bantoe waar is, geld inderdaad vir enige partikuliere kultuurvolk.

'n Mens kan wanneer jy met suiwere maatstawwe meet, moeilik tot ' $\mathrm{n}$ ander konklusie kom as dat die indiwidu nie vry is om die waardesisteme van sy groep te vernietig of te negeer nie. Die indiuidu kan nie los staan van sy groep nie, hy kan nie vernietig sonder om die indiwiduele vryheid van ander indiwidue aan te tas nie, want die gebondenheid van die indiwidu is inderdaad die vryheid van die totaalsom van indiwidue, m.a.w. die groep. En 'n mens moet daarop wys dat nòg indiwiduele menings nòg die wetenskap die reg het om verkleinerend te staan teen dic fundamentele reg en vryheid van 'n volk in sy geheel om sy identiteit en tradisie, m.a.w. sy selfbeskikking, te handhaaf teen bedreiging en vernietiging.

U sou gemerk het dat ek in die beklemtoning van gebondenheid binne die groep wat begrensing van indiwiduele vryheid meebring, die indiwidu nêrens die reg ontsê het om binne die waardesisteme van sy groep ook waardigheid te laat geskied aan die waardesisteme van andersoortige groepe nie. Die onderskrywing van eie waardesisteme beteken nie dat 'n mens die waardesisteme van ander moet verag, verkleineer 
of vernietig nie. Menswaardigheid teenoor andersoortige groepe kan gehandhaaf word sonder om eie waardesisteme oorboord te gooi. Tewens, dit is juis die onbeperkte beoefening van individuele vryheid in verhoudings wat norme van gelykmaking moet daarstel en in die proses noodwendig moet verag, verkleineer en ruïneer.

Ek het met ' $n$ belydenis begin en wil met ' $n$ stelling afsluit: Elke mens is wat hy is deurdat hy voortgebring is binne die omarming van waardesisteme van sy groep. Sy nakroos sal wees wat hulle sal wees deur die keuse wat hy as verwekker maak tussen die sekerheid in gebondenheid aan die waardesisteme van sy groep en die onsekerheid van die ongebaande weg waar indiwiduele vryheid moontlik heen mag lei. In die verhoudingspatrone in ons eie land mag ek my dan seker die vryheid veroorloof om $u$ as denkende groep te herinner aan die woorde van Barry Goldwater in sy boek The Conscience of a Conservative:

„Only a philosophy that takes into account the essential differences between men, and develop to the utmost the potentialities of each man, can claim to be in accordance with Nature."

Ek wil daarby voeg dat dit wat in ooreenstemming is met die Natuur sekerlik ook inpas in die Hoër Bedoeling van die Skepper van daardie Natuur. Net so min as wat indiwiduele vryheid verhewe staan bo die vryheid van die groep, net so min staan die menslike wese in sy doen en late verhewe bo die Skepper wat hom geskape het.

S.W.A.

J. P. van S. Bruwer.

\section{VERWYSINGS}

1. Bruwer, J. P.: Grondbeginsels i.v.m. Fisiese en Kulturele Verskille. Tydskrif vir Rasse-Aangeleenthede. Vol. 4. 1953.

2. Spengler, O.: The Decline of the West. Part 2, p. 5.

3. Carr-Saunders: The problem of Population, p. 453.

4. Pearson, Roger: Eugenics and Race, p. 40.

5. Pearson, Rogers: A.w., p. 21.

6. Oldham, J. A.: Christianity and the Race Problem, p. 30

7. Walter: Race and Culture Relations, p. 45.

8. Bruwer, J. P.: Aanhaling in: Theories based on the Concept of Race. Tydskrif vir Rasse-Aangeleenthede. Vol. 9. 1958.

9. Vilikazi, A.: African Studies. 1957.

10. Temples, P. P.: Bantoe-Filosofie. 1950.

11. Jahn, J. H.: Umuntu: Outline of Neo-African Culture. 1961.

12. Temples, P. P.: A.w. 